\title{
A Tale of Inconsistency: the Absence and Presence of Australia in the
}

\section{Historiography of Modern Architecture.}

Macarena de la Vega, PhD Candidate at the University of Canberra

\begin{abstract}
This essay addresses the following question: how has Australia been portrayed in the historiography of modern architecture? From the early twentieth to the twenty first century, from Henry-Russell Hitchcock to Jean-Louis Cohen, the presence of Australia in histories of modern architecture is inconsistent, with intermittent periods of absence. Similarly, the historians' choices of modern buildings and architects in Australia are inconsistent. This essay investigates the different editions and expansions of the histories of modern architecture with a focus on those published after 1957, the year of the competition of the Sydney Opera House designed by Danish architect Jørn Utzon. Just as the different buildings and architects are relevant for the argument of this essay, it is necessary to discuss the differences in the historians' own first-hand experience in Australia, as well as their also inconsistent use of limited sources. It is precisely this inconsistency in references, both built and written, that gives an idea of the lack of connection between the general historiography of modern architecture and the research that has been undertaken in Australia on the history of the country's modern architecture since 1984.
\end{abstract}

The aim of this essay is to discuss how Australian modern architecture has been portrayed in historiographical studies, a field defined by Panayotis Tournikiotis in his work The Historiography 
of Modern Architecture as concerned with "the writing of history, written history." 1 The book has been regarded as an "excellent analysis" which "must form the basis of any serious study of the works" of every historian of Tournikiotis' corpus by subsequent historiographer Anthony Vidler. ${ }^{2}$ In Gevork Hartoonian's opinion, Tournikiotis is the first scholar "to take into consideration the entire gamut of contemporary historiography of architecture."33 Tournikiotis' work is also the starting point of this essay for it provides the list of histories to look at, written by historians based in Europe and North America; a list that has been extended and updated by subsequent historiographical research. ${ }^{4}$ This essay's focus is not on Australian modern architecture, but on what historians of modern architecture in general have said about Australia and if so, when they did it. Given that most of the historians of modern architecture revised and expanded their work in subsequent editions, this essay investigates textual references to Australia in every edition of every history of modern architecture written in the twentieth and twenty-first centuries. And, more importantly, it studies the sources historians used to understand the development of modern architecture in Australia and asks if they even visited the country.

It is possible to establish a certain periodisation despite the inconsistency that characterises the presence and absence of Australia in general histories of modern architecture. This attempt of periodisation helps to clarify a structure in which different historians and different editions of their books overlap. ${ }^{5}$ Dating from American architectural historian, Henry-Russell Hitchcock’s Modern

\footnotetext{
${ }^{1}$ Panayotis Tournikiotis, The Historiography of Modern Architecture (Cambridge, MA.: The MIT Press, 1999), viii.

${ }^{2}$ Anthony Vidler, Histories of the Immediate Present: Inventing Architectural Modernism (Cambridge, MA.: The MIT Press, 2011), 201.

${ }^{3}$ Gevork Hartoonian, The Mental Life of the Architectural Historian: Re-opening the Early Historiography of Modern Architecture (Newcastle upon Tyne: Cambridge Scholars Publishing, 2011), 6.

${ }^{4}$ See Ángel Isac, "La historia de la arquitectura del siglo XX: modelos historiográficos," in Maria Pilar Biel Ibáñez and Ascensión Hernández Martínez, Lecciones de los maestros: aproximación histórico-critica a los grandes historiadores de la arquitectura española (Zaragoza: Institución 'Fernando El Católico' y Universidad de Zaragoza, 2009), 35-58 and Ana Esteban Maluenda, "Latinoamérica en la historiografía moderna," in La arquitectura moderna en Latinoamérica, ed. Ana Esteban Maluenda (Barcelona: Reverté Editorial, 2016), 291-339. See also Macarena de la Vega, "The Historiography of Modern Architecture: Twenty-Five Years Later," in Architectural Theory and History, ed. Stavros Aligragkis and Nicholas Patricios (Athens: Athens Institute for Education and Research, 2015), 3-17.

${ }^{5}$ See table.
} 
Architecture: Romanticism and Reintegration (1929) until the 1960s, historians neglect Australia in their narratives. Swiss art historian and critic, Sigfried Giedion discusses the Sydney Opera House: the international competition held in 1957 , the design and the construction as late as the fifth edition of Space, Time and Architecture: the Growth of a New Tradition (1967, originally published in 1941). Nevertheless, Giedion becomes the exception among the early historians for his attention to Australia.

If we trace the inclusion of Jørn Utzon and the Opera House, their appearance in histories published after 1957 is uneven. In the books first published in the 1960s and 1970s, some historians include Uzton's entry and some do not. While the building does not seem suit the agendas of the British historians, Reyner Banham and Peter Collins or of the Italian architectural historian, Manfredo Tafuri, other historians such as Leonardo Benevolo and Charles Jencks, respectively, mention and discuss the Opera House. It is not until the 1980s that not only the Sydney Opera House, but other examples in Australia appear in general histories of modern architecture. However, this does not mean that a certain consistency was finally achieved. There are differences between all editions of the books written by Kenneth Frampton and William J.R. Curtis, both British architectural historians and critics disseminating their research from American institutions. Furthermore, while the also British Alan Colquhoun fails to even mention the Sydney Opera House in Modern Architecture (2002), French architectural historian, Jean-Louis Cohen includes it and other Australian works in his account of modern architecture published in 2012.

This overview considers not only the different editions of histories of modern architecture from 1929 to 2012, but also the written sources, Australian or not, which historians used to build their accounts of Australia. From 1980 onwards, the knowledge and research on Australian modern architecture has increased exponentially. This is largely due to the work of the Society of 
Architectural Historians, Australia and New Zealand and of scholars in different universities around the country. Through their research and publications, unexplored, even unknown aspects of this architecture have been illuminated. Although there have been attempts at reframing Australian architectural history, these innovations appear not to have impacted contemporary architectural historiography.

\section{Absence in the early historiography}

Modern architecture famously made its appearance in Europe at the beginning of the twentieth century; its image consolidated with an exhibition held at the Museum of Modern Art in New York (MoMA) in 1932, entitled 'Modern Architecture: International Exhibition' organised by Henry-Russell Hitchcock and Philip Johnson. In the introduction to the exhibition's catalogue, the museum's director at the time, Alfred Barr announced a "new style" spreading around the world that has been called International Style. ${ }^{6}$ However, the term international, at that time, covered works built exclusively by central European, American, and Japanese architects.

Hitchcock and Johnson simultaneously worked on the preparation of the book, The International Style (1932), ${ }^{7}$ which included a wider range of architects than the catalogue and countries with an incipient modern architecture, at that time, like Spain. They excluded Japan. Hitchcock himself revisited the significance of this book in his subsequent work, Architecture: Nineteenth and Twentieth Centuries (1955) and in the prologue to the new edition of The International Style (1966). ${ }^{8}$ According to Hitchcock, the book's significance lay less on its content but rather on its timely appearance. Despite not being a history of modern architecture, according to Tournikiotis, The

\footnotetext{
${ }^{6}$ Catalogue Modern Architecture: International Exhibition (New York: Museum of Modern Art, 1932).

${ }^{7}$ Henry-Russell Hitchcock and Philip Johnson, The International Style: Architecture Since 1922 (New York: W. W. Norton, 1932).

${ }^{8}$ Henry-Russell Hitchcock, Architecture: Nineteenth and Twentieth Centuries (Harmondsworth: Penguin, 1958). Reprinted with foreword and appendix by Hitchcock, The International Style (New York: W. W. Norton, 1966).
} 
International Style needs to be included as "a work of history" and one of the most influential on subsequent interpretations of modern architecture. ${ }^{9}$

In fact, Hitchcock's Modern Architecture: Romanticism and Reintegration (1929), had been the first history of modern architecture and the only one written by an American scholar in English,not in German as was customary during the 1920 s and 1930 s. $^{10}$ This previous historiography, written in German and profusely illustrated, included Walter Gropius' Internationale Architektur (1925), Adolf Behne's Der moderne Zweckbau (1926), Walter C. Behrendt's Der Sieg des neuen Baustils (1927), Ludwig Hilberseimer's Internationale neue Baukunst (1927), Gustav Platz's Baukunst der neusten Zeit (1927), Sigfried Giedion's Bauen in Frankreich (1928), and Bruno Taut's Die neue Baukunst in Europa und Amerika (1929). With the exceptions of Giedion and the art critic Behne, these authors were all practicing architects.

Following the MoMA exhibition, the field of the histories of modern architecture began to gather momentum when the German art historian Nikolaus Pevsner published Pioneers of the Modern Movement: from William Morris to Walter Gropius (1936) in London, after being forced to resign his lectureship at the University of Göttingen by the Nazis. ${ }^{11}$ It took Pevsner thirteen years, a selection of new images, and several corrections to publish the second edition in which the main change was not in the content but in the title -he substituted Movement for Design. ${ }^{12}$ Pevsner revised substantially Pioneers of Modern Design in 1960, including only a new paragraph at the end

\footnotetext{
${ }^{9}$ Tournikiotis, The Historiography of Modern Architecture, 142.

${ }^{10}$ Henry-Russell Hitchcock, Modern Architecture: Romanticism and Reintegration (New York: Payson \& Clarke, 1929). See Macarena de la Vega, "A Historical Legacy: Henry-Russell Hitchcock and Early Modernism," Cuaderno de Notas, n'16 (July 2015): 73-78. Previously published as the postscript to the Spanish translation of the book.

${ }^{11}$ Nikolaus Pevsner, Pioneers of the Modern Movement: from William Morris to Walter Gropius (London: Faber \& Faber, 1936).

${ }^{12}$ Nikolaus Pevsner, Pioneers of Modern Design: from William Morris to Walter Gropius (New York: Museum of Modern Art, 1949).
} 
summarising what had happened since 1914, where his history ended. ${ }^{13}$ Indeed, he did not see the point in looking beyond $1914 .^{14}$

Sigfried Giedion's Space, Time and Architecture (1941) widened Pevsner's vision: first, it highlighted the importance of engineering works and, second, itstudied modern architecture until 1940. ${ }^{15}$ Giedion's account, as with Pevsner's, is characterised by his commitment to the architecture he was historicising. As the "epitome" of the classical surveys of modern architecture, it perpetuated a construct that represented "twentieth-century European modernism as the unique and rational expression of modern industrial society and the teleological destiny of architectural development everywhere else."16 Two further editions were published without much modification in 1949 and 1954. The fourth edition appeared in 1962, with a new preface where Giedion explained how he had refused to add a second volume with more recent works and an introduction about the architectural climate of 1960 . Four years later, Giedion prepared a new edition with numerous changes in the entire text and with important additions. This fifth edition (1967) acknowledged the Sydney Opera House for the first time in the historiography of modern architecture, which will be analysed further on.

The next book in this first period of absence is Storia dell'architettura moderna (1950) by the Italian architect Bruno Zevi. ${ }^{17}$ The aim was to address other modern architectures, architects, and movements, outside of the canon and methodology established by the early historians of modern architecture, questioning without rejecting their positions. According to Jean-Louis Cohen, Zevi's

\footnotetext{
${ }^{13}$ Third edition revised and expanded, Pioneers of Modern Design: From William Morris to Walter Gropius (Harmondsworth: Penguin, 1960).

${ }^{14}$ Nikolaus Pevsner, "Architecture in Our Time, the Anti-pioneers," The Listener, no. 29 (December 1966).

${ }^{15}$ Sigfried Giedion, Space, Time and Architecture: the Growth of a new Tradition (Cambridge, MA.: Harvard University Press, 1941).

${ }^{16}$ Sibel Bozdogan, "Architectural History in Professional Education: Reflections on Postcolonial Challenges to the Modern Survey," Journal of Architectural Education 52, no. 4 (May 1999): 208.

${ }^{17}$ Bruno Zevi, Storia dell 'architettura moderna (Turin: Einaudi, 1950).
} 
history did not forget the relationship between architecture and politics, and considered a wide range of buildings. ${ }^{18}$ Zevi revised and updated his history with facts, comments, and additional images almost until his death in 2000. Despite his inclusiveness, he was not concerned with countries and regions outside of Europe and the United States, with the exception of Brazil and their reception of Le Corbusier's work.

Hitchcock wrote the above-mentioned Architecture: Nineteenth and Twentieth Centuries (1958) in London so that he could visit works all over Europe. An interesting feature about this first edition is that all images were grouped at the end -organised by relations and similarities, and not by countries- building a graphic discourse as important as the written one (it was suppressed in 1971 when the images were integrated in the main body of the text). Surprisingly, in the first edition of 1958, there were two brief mentions to Australian architecture, though not modern architecture. Firstly, in the chapter on 'The New World' Hitchcock mentioned Francis Greenway, how he became Governor Macquarie's architect, and how "his house of 1822 for Robert Campbell, Jr, in Bligh Street in Sydney showed that he had real skill as a designer of up-to-date Regency villas."19 Secondly, Hitchcock included Greenway's Government House Stables in Sydney in the list of examples of the Gothic Revival. ${ }^{20}$ As early as 1958 there are brief mentions of Australian colonial architecture as part of a global image of architecture.

The last edition of Hitchcock's book (1977) included an epilogue on works and architects since 1958. Architects "unknown internationally" in the mid 1950s whose work was "of rising consequence" in the 1960s are not included in the main body of the text because Hitchcock stated he was not interested in merely listing name. ${ }^{21}$ In the note that accompanies this statement, the

\footnotetext{
${ }^{18}$ Jean-Louis Cohen, L'architecture au futur depuis 1889/ The Future of Architecture since 1889 (Paris: Phaidon, 2012).

${ }^{19}$ Hitchcock, Architecture: Nineteenth and Twentieth Centuries (1958), 141.

${ }^{20}$ Hitchcock, Architecture: Nineteenth and Twentieth Centuries (1958), 159.

${ }^{21}$ Hitchcock, Architecture: Nineteenth and Twentieth Centuries (1977), 578.
} 
author claimed that "the Dane Jørn Utzon rose to international fame and then sank again, thanks to the controversies concerning the Sydney Opera House in Australia." ${ }^{22}$ Hitchcock uses the building's complicated construction process, which will be thoroughly discussed further on, to justify not only Utzon's fame but also his brief mention to the Opera House, poor evidence of Australia's inclusion in his history.

Meanwhile, the 1960s were characterised by a new perspective. One of the best examples of this historiographical shift is Reyner Banham's Theory and Design in the First Machine Age (1960). ${ }^{23}$ According to Tournikiotis, history was for Banham a means to theorise and address the inconsistencies of the modern movement in the search for a new architecture. Banham believed that modern architects had not been able to make the best of the technology of their time. Just five years later, Peter Collins published Changing Ideals in Modern Architecture (1750- 1950). ${ }^{24}$ In Collins' account, the Modern Movements crystallized in 1890 due to the appearance of the technological innovations that formalised the ideas (and ideals) of Enlightenment, and not in the 1920s and 1930s, as claimed by previous historians. Manfredo Tafuri ended the decade with Teorie e storia dell'architettura (1968), in which he proposed a critique of architecture, which, according to Tournikiotis, he understood as the means for a revolutionary education aiming at a radical shift in the capitalist society. ${ }^{25}$ Tafuri mentioned Utzon only once when he discussed Giedion's Space, Time and Architecture in the chapter on 'Operative Criticism. ${ }^{26}$ Once again, this brief mention is insufficient for advancing Australia's presence in the historiography of modern architecture.

The early histories presented a phenomenon rooted mainly in central Europe and the United States, complemented with mention of Japan, and, especially in Hitchcock's case, of Latin America, yet

\footnotetext{
${ }^{22}$ Hitchcock, Architecture: Nineteenth and Twentieth Centuries (1977), 630.

${ }^{23}$ Reyner Banham, Theory and Design in the First Machine Age (London: The Architectural Press, 1960).

${ }^{24}$ Peter Collins, Changing Ideals in Modern Architecture (1750-1950), (London: Faber \& Faber, 1965).

${ }^{25}$ Manfredo Tafuri, Teorie e storia dell'architettura (Bari: Laterza, 1968).

${ }^{26}$ Manfredo Tafuri, Theories and History of Architecture (London and New York: Granada, 1980), 154.
} 
leaving Australia out of their narratives. All the histories discussed above had revised editions that appeared after the competition for the Sydney Opera House in 1957. However, as it happened with Pevsner's Pioneers, not all of them updated and extended the scope of their books. Pevsner, Zevi, Banham, and Collins wrote their histories without mentioning this iconic building. Apart from brief mentions by Hitchcock and Tafuri, only Giedion included Utzon's building in his history, and this too only in the fifth edition. Australian architecture was persistently absent from the early phases of modern historiography.

\section{First appearance in a non-first edition}

In the foreword to the fifth edition of Space, Time and Architecture (1967), Giedion mentions the addition of a new chapter on Jørn Utzon and the younger generation of modern architects, refered to as the third generation. An image from the Sydney Opera House and the harbour is the first illustration of the book. In the introduction on 'Architecture in 1960s: Hopes and Fears', Giedion lists Felix Candela, Eduardo Torroja, Pier Luigi Nervi, Kenzo Tange, and Utzon for their vaulted solutions. "Several sensitive characteristics of the third generation are sharply delineated" in the Danish architect, he observes. ${ }^{27}$ According to Giedion, the third generation of modern architects had a different attitude towards the past and the monumental character of the standalone building; they used previous architectural knowledge to frame contemporary approaches.

Giedion's account of the Sydney Opera House is organised in three parts: the competition, the architectural form, and the construction. Firstly, he points out how "in 1957 he [Utzon] was surprised to find he had won the competition for the Sydney Opera House in Australia." ${ }^{28}$ Giedion highlights the role played by Eero Saarinen as part of the competition's jury, in his defence of Utzon's project. According to the historian, Saarinen went through the projects that had been

\footnotetext{
${ }^{27}$ Giedion, Space, Time and Architecture (1967), 672.

${ }^{28}$ Giedion, Space, Time and Architecture (1967), 673.
} 
discarded, found, and recognised "the world significance of Utzon's entry." 29 Saarinen "returned to the jury with it and said 'Gentlemen, this is the first prize,"” writes Giedion. ${ }^{30}$

Furthermore, in keeping with the third generation's approach, Utzon was "able to have direct contact with the cosmic elements of nature and the past and also complete control of contemporary methods of industrialised production -especially prefabrications," in Giedion's view. ${ }^{31}$ Utzon bases his design in segments of a sphere, a form "in which both the ever constant and the ever changing are inherent;" an understanding of form that is mark and symbol of the third generation and the new period in architecture. ${ }^{32}$ Giedion remembers how Utzon sent him from Australia "three wooden balls, from which he had sliced the different segments of his vaults," which "show that the curves of his vaults are far from arbitrary." 33

In disagreeing with the alleged arbitrariness of the vaults of the Sydney Opera House, Giedion defends 'the autonomous right of expression' as the way for the third generation to assert themselves and the result of their "master hand." ${ }^{34}$ He makes a very interesting point: the shells or staggered vaults are subject to widespread objection for being "arbitrary" and "superfluous," but only if we take into account their function. ${ }^{35}$ Giedion argues that this objection raises a question of conscience at that time: "Are we prepared to go beyond the purely functional and tangible as earlier periods did in order to enhance the force of expression?" ${ }^{36}$ This right of expression is Giedion's tool to justify not only the form but also the cost necessary to materialise it due to the difficult construction process. For Giedion, it is unprecedented and "highly significant" that the building

\footnotetext{
${ }^{29}$ Giedion, Space, Time and Architecture (1967), 673.

${ }^{30}$ Giedion, Space, Time and Architecture (1967), 673.

${ }^{31}$ Giedion, Space, Time and Architecture (1967), 678.

${ }^{32}$ Giedion, Space, Time and Architecture (1967), 679.

${ }^{33}$ Giedion, Space, Time and Architecture (1967), 679.

${ }^{34}$ Giedion, Space, Time and Architecture (1967), 677.

${ }^{35}$ Giedion, Space, Time and Architecture (1967), 677.

${ }^{36}$ Giedion, Space, Time and Architecture (1967), 677.
} 
construction was handed over to a committee in charge of making the details of the building simpler and cheaper by introducing major changes, and disregarding Utzon's individualised design, which caused him to resign. ${ }^{37}$ The historian asks: "Why all this? Why this expenditure of time and money? The unyielding tenacity with which this right of expression was upheld opens a new chapter in contemporary architecture." ${ }^{38}$

Giedion reflects on the role of the historian in cases as unique as the Sydney Opera House and the debate it generated at the time, saying that it " is a moral duty for the historian to stand up for the real qualities of one of the most outstanding works of this period." ${ }^{39}$ The obedience to the eternal architectural law is, according to Giedion, the real quality of the Opera House and sign of the close relationship between architecture and geometry. Giedion defends the shells and the different intentions of the interior and the exterior of the building using the example of the Pantheon. He advocates for the Opera House to be understood as a "totality, and above all, [for] how it fulfils its human purpose" which is to prepare the audience for a festival. ${ }^{40}$

There is an evident bias in Giedion's narrative of the Sydney Opera House. This may be apprehended given the intimate relationship between the historian and the architect, evident in their correspondence and in the fact that Utzon's writings and reflection on this building are Giedion's only source. For Giedion, the shells are "symptomatic" of their time in their form, in their construction method, and in their social meaning. ${ }^{41}$ He returns to Saarinen and how "he recognised from the beginning that the Sydney Opera House would be one of the great buildings of our period." ${ }^{42}$ It is significant to note that, at the time Giedion wrote this analysis, the Opera House had

\footnotetext{
${ }^{37}$ Giedion, Space, Time and Architecture (1967), 685.

${ }^{38}$ Giedion, Space, Time and Architecture (1967), 684.

${ }^{39}$ Giedion, Space, Time and Architecture (1967), 688.

${ }^{40}$ Giedion, Space, Time and Architecture (1967), 688.

${ }^{41}$ Giedion, Space, Time and Architecture (1967), 695.

${ }^{42}$ Giedion, Space, Time and Architecture (1967), 688.
} 
not yet been finished -it was inaugurated on 20 October 1973- and he could only guess the social impact the building would have. His judgement and committed defence of this project was considered at least premature by succeeding historians of modern architecture, but I would add, not mistaken.

\section{'Just' the Sydney Opera House}

During the 1960s and 1970s the presence (if present; the absences until the 1960s have already been acknowledged) of Australia in the histories of modern architecture was restricted to the Sydney Opera House. The next historian in this overview, Leonardo Benevolo, had been educated as architect and historian through the histories by Pevsner, Giedion, and even Zevi. In Storia dell'architettura moderna (1960) Benevolo studies the origins of modern architecture in the profound changes around $1750 .{ }^{43}$ His aim is to address the present and he updates the content in the subsequent editions with significant additions: chapters on specific countries written by other historians. Only in the later editions of the book, Benevolo briefly mentions Utzon's Opera House within the context of architectural shifts from 1960, to illustrate and exemplify the trend of open international competitions for representative buildings. ${ }^{44}$

The place of the Opera House in histories of modern architecture expands in the following decade in the work of the American architectural theorist and landscape architect Charles Jencks. Modern Movements in Architecture (1973) is the result of his doctoral dissertation supervised by Banham, whose Theory and Design was also the result of his doctoral thesis supervised by Pevsner. ${ }^{45}$ The book sets a new critical standard and radically rejects the early historiographical interpretations of the Modern Movement. Jencks adds a new tag, late modern, to classify works that did not follow

\footnotetext{
${ }^{43}$ Leonardo Benevolo, Storia dell'architettura moderna (Bari: Laterza, 1960).

${ }^{44}$ Benevolo, Historia de la arquitectura moderna (Barcelona: Gustavo Gili, 1987, $6^{\text {th }}$ edition), 1020. Author's translation into English.

${ }^{45}$ Charles Jencks, Modern Movements in Architecture (Harmondsworth: Penguin, 1973).
} 
the Modern orthodoxy, but could not be considered post-modern. He includes Utzon in the intuitive tradition -as one of 'The Six Traditions: Politics and Architecture' discussed in the first chapter of the book- together with Bruno Taut, the Expressionists, Pier Luigi Nervi, Frei Otto, Felix Candela, and Hans Scharoun. This list develops Giedion's line up of architect's employing vault solutions in the 1960s, further linking these architects with the precedent of Expressionism. Jencks portrays Utzon as the example of "the point at which insistence on individual creativity became politically and functionally fantastic." ${ }^{46}$ Interestingly, he discusses Utzon's shells -which he described as fantastic, extravagant, and inefficient- in terms of their appropriateness. Giedion's focus in contrast is on the buildings' and architect's right of expression. Jencks writes:

The shell vaults, inefficient as structure, were to hold acoustic ceilings some distance below and were meant to recall the billowing sail boats and waves of the harbour -a quite fantastic association both in terms of cost and appropriateness. The cost grew from an underestimated $\$ 7$ million in 1960 to over $\$ 70$ million. $^{47}$

In Jencks' opinion, the building is questionable both on an architectural and a socio-political level. On an architectural level, the form of the Opera House could be questioned for the lack of appropriateness of the shells to the function of the building. Jencks uses the spherical origin of the form to point out how it has not "anything specific to do with an opera house, or with music as in the case of Sharoun" and his Philarmonie. ${ }^{48}$ On a socio-political level, Jencks considers the building questionable for elevating "opera to a position of priority within the spectrum of civic activities-a place usually reserved for religious buildings or some kind of community centre," disregarding the changes made to the program in order to accommodate more uses. ${ }^{49} \mathrm{He}$ argues:

\footnotetext{
${ }^{46}$ Jecks, Modern Movements in Architecture (1973), 66.

${ }^{47}$ Jecks, Modern Movements in Architecture (1973), 67.

${ }^{48}$ Jecks, Modern Movements in Architecture (1973), 66.

${ }^{49}$ Jecks, Modern Movements in Architecture (1973), 67.
} 
Consider those explicitly cultural commissions which society has given its major architects: the Guggenheim Museum and Lincoln Centre in New York, the Opera House in Sydney, and the Royal Festival Hall in London. Each one of these projects is formally interesting, but each one is being asked to fulfil a role in city life which was previously filled either by the church or state. ${ }^{50}$

While for Giedion the building is an excuse to reflect on the task of the historian, Jencks uses it to frame his reflection on the task of the architect and the importance of society in cultural commissions. In the post-script to the 1973 edition on 'Architecture and Revolutions' -later changed in the 1987-postscript for 'Late-Modernism and Post-modernism'- he urges for social changes in order to achieve a "viable architecture," one that can be built without causing social debt, due to exceeding the proposed budget. ${ }^{51}$

When compared with previous histories, Renato De Fusco's Storia dell'architettura contemporanea (1974) was meant to be read by students and a generally unspecialised audience. ${ }^{52}$ As a result, he presented a reduced, basic, and systematic organisation of modern architecture, its significance, and structure, which also excluded Australia. This serves to make him a noteworthy exception at this time, almost twenty years after the competition of the Opera House. Also in Italy, Tafuri and Francesco Dal Co published Architettura contemporanea (1976) as part of a universal history of architecture coordinated by Pier Luigi Nervi. ${ }^{53}$ According to William Curtis, this book focussed on the development of the modern industrial city mainly in North America and Europe, rather than on buildings or architects. The authors very briefly mention Reima Pietilä and Jørn Utzon, “the Danish

\footnotetext{
${ }^{50}$ Jecks, Modern Movements in Architecture (1973), 372.

${ }^{51}$ Jecks, Modern Movements in Architecture (1973), 372.

${ }^{52}$ Renato De Fusco, Storia dell'architettura contemporanea (Roma and Bari: Laterza, 1974).

${ }^{53}$ Manfredo Tafuri and Francesco Dal Co, Modern Architecture (London: Academia Editions, 1980). Architettura contemporanea (Milan: Electa, 1976).
} 
architect of the Sydney Opera House," when discussing how, for Saarinen, "the neurosis is generated by the obsessive preoccupation with restoring meaningful depth to a repertory of inherited forms that are devoid of meaning in themselves." 54

In examining all these historians, it can be seen that Jencks' was the most relevant contribution to the field in relation to the Sydney Opera House. Indeed, it is the first mention of modern architecture in Australia in a first edition. The way he presents the public debate caused by the building's complicated construction process clearly opposes Giedion's account, introducing in the debate the appropriateness of the building's cost for the Australian government and society. The very brief mentions of the building in subsequent histories by Benevolo, and Tafuri and Dal Co are evidence, again, of the inconsistency of the presence of the Sydney Opera House -as uniquely representative of modern architecture in Australia- in the historiography of modern architecture, at least, until the late 1970 s.

\section{Ambivalence in the late historiography}

From 1980 onwards, new histories of modern architecture were published. Kenneth Frampton's Modern Architecture: A Critical History (1980) sets the origins of modern architecture in 1750 and, in its first edition, covers a period up to the end of the $1970 \mathrm{~s}^{55}$ It has been considered "both a history and a collection of essays" ${ }^{\prime 56}$ and the replacement of Giedion's book as the primary survey of modern architecture. ${ }^{57}$ Frampton reflects on different concepts and relates them to build his discourse, organised thematically and not chronologically. The second edition, appeared in 1985 with an extra chapter on 'Critical Regionalism: Modern Architecture and Cultural Identity,' and the third in 1992 with another on 'World Architecture and Reflective Practice' and an introduction

\footnotetext{
${ }^{54}$ Tafuri and Dal Co, Modern Architecture, 378.

${ }^{55}$ Kenneth Frampton, Modern Architecture: A Critical History (London: Thames and Hudson, 1980).

${ }^{56}$ Maluenda, "Latinoamérica en la historiografía moderna," 319. Author's translation into English.

${ }^{57}$ Bozdogan, "Architectural History in Professional Education,” 209.
} 
where "Frampton makes an apology for not having included recent work from India, Australia, Canada, Latin America, and the Middle East." ${ }^{, 5}$ Since Australia does not appear until the fourth edition in 2007, Frampton's inclusion of Australia in his Modern Architecture will be discussed further on.

William J. R. Curtis finalised his own history, Modern Architecture Since 1900 (1982) during this same period. ${ }^{59}$ The book had a second edition in 1987 with an updated chapter or addendum and a third edition, reorganised, expanded and published in 1996. In Curtis' opinion, Australian and Indian "modern architecture had to begin from scratch," scratch"61 in the third edition. He considers Australia within a range of countries where the reception of "bastardized and stereotyped" images from the United States after the war was proof of the international victory of modern architecture.$^{62}$ Curtis also discusses the particularities regarding the Aboriginal population and the debates on the problem of an Australian cultural identity. He uses the word tension to refer to the Australian tradition (or lack of it) being complicated "by the relatively recent arrival of Europeans and by the fact that the Aboriginal population expressed its ideas through other means than permanent buildings." 63

The first architect mentioned, though briefly, is the American architect, Walter Burley Griffin as responsible for introducing "Wrightian" forms in Australia. ${ }^{64}$ Similarly, Curtis presents Austrian-born architect, Harry Seidler's cosmopolitan education in England, Canada, and the United States as responsible for introducing universalizing ideas and imitations of eastern American architectural language in Australia, where he migrated from New York. The slight changes Seidler

\footnotetext{
${ }^{58}$ Bozdogan, "Architectural History in Professional Education,” 209.

${ }^{59}$ William J. R. Curtis, Modern Architecture Since 1900 (London: Phaidon Press, 1982). See also Author's citation.

${ }^{60}$ Curtis, Modern Architecture Since 1900 (1982), 258.

${ }^{61}$ Curtis, Modern Architecture Since 1900 (1996), 397.

${ }^{62}$ Curtis, Modern Architecture Since 1900 (1996), 396. (1982, 258).

${ }^{63}$ Curtis, Modern Architecture Since 1900 (1996), 503-04.

${ }^{64}$ Curtis, Modern Architecture Since 1900 (1996), 504.
} 
made are, in Curtis' opinion, evidence of his strong modernist position. Curtis uses a quote by Paul Rudolph to state how the Rose Seidler's House (1948) is "the Harvard house incarnate transferred to Sydney without any modification whatsoever." ${ }^{65}$ Harry Seidler's "foreignness," is listed by Curtis, together with the "modern regionalism" of Peter Muller, born in Adeleide; the brutalist ideology of Peter Johnson, born in Armadale, Victoria; and the "casualness of a new suburban way of life" defended by the Sydney architects William Lucas and Neville Gruzman, as an attempt at producing a new Australian architecture. ${ }^{66}$ Together with the work of other architects practicing in Sydney in the late 1950s and 1960s, their domestic architecture resulted in what has been called the Sydney School. Curtis avoids the term in all editions, even if he acknowledges that they "developed an analogous aesthetic." ${ }^{67}$

Much of Curtis' account of modern architecture in Australia is devoted to the Sydney Opera House. However, for him, it is more the result of Utzon's reception of the Scandinavian tradition than a product of Australian architecture. Following in Giedion's footsteps, Curtis gives more importance to the aims behind the design's section than to Arup's structural solution. There are three main ideas in Curtis' analysis of this iconic building: its originality, its symbolism, and its significance. Firstly, the newness of the Opera House makes it a prototype, as are most works of art, with limited sources or analogies. Secondly, Curtis agrees with Philip Drew and with Utzon himself in considering the building as a modern cathedral, consecrating its symbolism to a "supremely important national art." ${ }^{68}$ Thus, he disregards the point raised by Jencks about the lack of appropriateness of the opera as the art to fulfil a social purpose. Thirdly, the choice of this building as an icon of the second half of the twentieth century architecture was, according to Curtis, premature. At the time this choice was

\footnotetext{
${ }^{65}$ Curtis, Modern Architecture Since 1900 (1996), 504. (1982, 336).

${ }^{66}$ Curtis, Modern Architecture Since 1900 (1996), 504. (1982, 336).

${ }^{67}$ Curtis, Modern Architecture Since 1900 (1996), 505.

${ }^{68}$ Curtis, Modern Architecture Since 1900 (1996), 469. (1982, 304).
} 
made, especially by Giedion as has been discussed above, it was not clear how buildable Utzon's design was.

Finally, in the last chapter of the first edition, Curtis includes a detailed account of the entry to the competition for a new Australian Parliament building in Canberra, 1980 by New York-based architect Romaldo Giurgola. He was born in Italy where he studied to be an architect and continued his education in the United States, where he also became a scholar. Curtis describes the parliament project as "a virtual inventory of contemporary preoccupations" and focusses his interest on Giurgola's gesture of "blending the building with its context." ${ }^{69}$ Curtis presents the building as having an "appealing collagist aspect."70 Interestingly, the reference to the Parliament building competition is suppressed from the third edition of Modern Architecture Since 1900.

There are two main additions to the content of the third edition which refer to Griffin and to Glenn Murcutt, who despite being British-born is generally considered the best-known Australian architect. Curtis goes into more detail on Griffin's work and regards his plan for the new capital city of Canberra (1912) as "an organic conception blending a non-authoritarian monumentality with a dispersed garden city," and his Newman College in Melbourne (1918) as "a hybrid of modern skeletal thinking, abstracted Gothic motifs, and vaguely geological metaphors." ${ }^{, 71}$ The Australian domestic architecture of the 1970s and 1980s exemplified by Rick Leplastrier's Palm House in Sydney (1974), and the response to different climatic zones given by Glenn Murcutt's Ball-Eastaway House in Glenorie (1983) are for Curtis examples of the notion "blend of universalisms" rather than regionalism. ${ }^{72}$

\footnotetext{
${ }^{69}$ Curtis, Modern Architecture Since 1900 (1982), 382.

${ }^{70}$ Curtis, Modern Architecture Since 1900 (1982), 382.

${ }^{71}$ Curtis, Modern Architecture Since 1900 (1996), 299.

${ }^{72}$ Curtis, Modern Architecture Since 1900 (1996), 640.
} 
These additions to the third edition of Modern Architecture Since 1900 give an idea of the broad expansion of the account of Australian architecture in historiography. Curtis includes Australian examples designed over a period of time of seventy years and discusses them thematically throughout the book in relation to the continuity of other older traditions in the crystallization of modern architecture between the wars, to the process of absorption of modern influences in countries outside Europe and North America after 1940, and to the notion of landscape in the late twentieth century.

The British architect and scholar Alan Colquhoun wrote Modern Architecture (2002) as emeritus professor of architecture at Princeton University. His aim was to summarise the main ideas and most relevant works until the year 1965. He did not find in Australia any example significant enough to mention in his global and succinct overview of modern architecture. Still, at the beginning of the twenty first century, Colquhoun continued the tradition of writing about modern architecture focussing on experiences in central Europe, the United States, Japan, and, very briefly, Latin America.

Frampton added a chapter on 'Architecture in the Age of Globalization: Topography, Morphology, Sustainability, Materiality, Habitat, and Civic Form 1975-2007' to the fourth edition of Modern Architecture: A Critical History (2007). This was done twenty-seven years after the publication of the first edition and exactly fifty years after the international competition for the Opera House, providing his narrative with the arguably desired historical distance. The only reference to the Opera House appears when Frampton discusses the notion of topography using as examples the Miró Foundation in Mallorca (1975) and the Kursaal Auditorium and Congress Centre in San Sebastian (1999), both in Spain. In his opinion, "it seems hardly accidental that the relationship established between the building and the water parallels that achieved by Jørn Utzon in the Sydney 
Opera House (1957-73): Moneo worked as an assistant for Utzon on this project soon after his graduation from Madrid in 1961..73

After briefly mentioning Murcutt in his investigation of topography, Frampton discusses his work in more depth under the notion of sustainability. He emphasizes the construction system of the Marie Short House in northern New South Wales (1974) where "because of the relative remoteness of these houses, Murcutt felt obliged to employ a constructional repertoire with which rural builders were familiar." ${ }^{\text {"4 }}$ Murcutt refined the format of his houses' construction system and developed over twenty years what Frampton calls his standard or "enhanced ecological profile" exemplified in the Marika-Alderton House (1994). ${ }^{75}$ This house and the defensive character of having a clear view of the horizon is also the excuse used by Frampton to briefly introduce Aboriginal culture in his narrative. Finally, Frampton links Murcutt's use of cantilevered walls in both the Marika-Alderton House and the Boyd Education Centre (1999) with Le Corbusier's use of brise-soleil. This last building is regarded by the historian as "the first truly civic work in Murcutt's career.",76

Based in New York, just like Frampton, the French historian Jean-Louis Cohen wrote the last, and most recent history of modern architecture to date: L'architecture au futur depuis 1889 (2012). He is interested in expanding the field to include art, urbanism and technology and to understand the ideas and narratives behind both built and unbuilt architectural projects. Cohen's narrative highlights the importance of all that has to do with France and the French colonies "already from the title that marks the beginning of what he confusingly names "the future of architecture" in 1889 -year of the International Exhibition in Paris which commemorated the storming of the Bastille and

\footnotetext{
${ }^{73}$ Frampton, Modern Architecture: A Critical History (2007), 353.

${ }^{74}$ Frampton, Modern Architecture: A Critical History (2007), 364.

${ }^{75}$ Frampton, Modern Architecture: A Critical History (2007), 364.

${ }^{76}$ Frampton, Modern Architecture: A Critical History (2007), 364.
} 
which most iconic legacy is the Eiffel Tower." ${ }^{, 77}$ Despite the importance of France in the content of the book, Cohen includes Australia.

Cohen discusses Burley Griffin's plan for Canberra as example of capitals erected on new sites and evidence Wright's influence on him. He mentions how the American's entry won the international competition over Eliel Saarinen and Donat-Alfred Agache, a French planner. According to Cohen, in the "winning scheme, the city encroached on the surrounding areas, making repeated use of elements borrowed from the Prairie Houses that Griffin had drafted as an employee in Frank Lloyd Wright's office." 78

Cohen analyses the Sydney Opera House in the chapter on 'Repression and Diffusion of Modernism: Archipelagos of Invention,' as one of the cultural projects that certain cities used "to assure themselves a place on the world map." beginning of the global architecture phenomenon of the modern building as an urban attractor." ${ }^{, 80}$ Cohen follows Giedion in pointing out that the shells are the result of sections of a sphereand Jencks in linking the building's forms to an allusion of the sails of the ships and to German Expressionism, in general, and to Hermann Fisterlin, in particular. He reuses the Opera House later in his narrative, this time following in Frampton's footsteps, as an example of what the Kursaal Cultural Centre by Moneo means to the city of San Sebastian. ${ }^{81}$

Both Seidler and Murcutt are introduced by Cohen in his narrative under an epigraph named 'Research in South Asia' (instead of the Asia Pacific region), after briefly commenting on India and

\footnotetext{
${ }^{77}$ Luis Fernández-Galiano, “La óptica francesa: otra historia del siglo XX,” Arquitectura Viva, no. 144 (2012): 77. Author's translation into English.

${ }^{78}$ Cohen, The Future of Architecture since 1889, 80.

${ }^{79}$ Cohen, The Future of Architecture since 1889, 377.

${ }^{80}$ Cohen, The Future of Architecture since 1889, 377.

${ }^{81}$ Cohen, The Future of Architecture since 1889, 432.
} 
Sri Lanka. In the same paragraph he starts with how "Harry Seidler began designing architecture in the 1950s responding to Australia's need for modernization" and moves on to how "more radical propositions rooted in the country's building culture came from Glenn Murcutt. ${ }^{" 82}$ Cohen chooses Australian architect Kevin Borland's Nichols House (1973), built outside of Melbourne, and Murcutt's Simpson-Lee House, developed between 1988 and 1993 in the Blue Montains outside of Sydney, as examplesbuilt in the bush and transformed into inhabitable sculptures by the use of corrugated metal. In the chapter on high-tech architecture he mentions the office tower and residential block Aurora Place (2000) in Sydney as one of the skyscrapers were Renzo Piano "extended the principle of servant and served spaces vertically, at the same time giving a genuine tectonic complexity to the building skins." ${ }^{\prime 3}$

The account of Australian modern architecture in recent historiography is undoubtedly more detailed and complete. These recent accounts show a deeper understanding of Australian architecture and culture grounded, again undoubtedly, on their own experiences. Following in the footsteps of Pevsner and Banham, who visited Australia in 1956 and 1962 respectively, Jencks visited the country in 1974. Curtis visited Australia three times between 1980 and 1981 while working on the first edition of Modern Architecture Since 1900. Frampton was invited to Sydney to give a lecture on 'Critical Regionalism' at the RAIA Conference 'The City in Conflict' held in Sydney in 1983. He then visited the country again in 2004 and on both occasions he was interviewed for Architecture Australia. Frampton has also edited books on Harry Seidler and Glenn Murcutt. ${ }^{84}$ Jean-Louis Cohen recently visited Australia for the first time in July 2017 as keynote speaker of the $34^{\text {th }}$ conference of the Society of Architectural Historians, Australia and New Zealand. The fact that Colquhoun failed to even mention the Sydney Opera House is demonstrative

\footnotetext{
${ }^{82}$ Cohen, The Future of Architecture since 1889, 433.

${ }^{83}$ Cohen, The Future of Architecture since 1889, 441.

${ }^{84}$ Kenneth Frampton and Philip Drew, Harry Seidler: Four Decades of Architecture (London and New York: Thames \& Hudson, 1992). Kenneth Frampton, Glenn Murcutt, architect (Rozelle, NSW.: 01 Editions, 2006).
} 
of the inconsistency of the presence of Australia in the entire scope of the historiography of modern architecture. The differences in the relatively recent choices of architects and buildings made by Curtis (1982, 1996), Frampton (2007), and Cohen (2012) could be indicative of the poor international impact of the research undertaken in Australia by Australian historians.

\section{The writing of history in Australia}

This essay has demonstrated that Australian modern architecture has been mostly absent or, at least, under-represented in the histories of modern architecture published in Europe and North America with two main exceptions. Firstly, Giedion's in depth analysis of the Sydney Opera House which has to do more with Utzon than with Australia, and which was contested by Jenck's interpretation. The second exception is the extensive treatment of Australian modern architecture in most of the histories published from 1980. Among them, it is relevant to highlight the third edition of Curtis' Modern Architecture Since 1900 not only for providing the reader with the most complete account, but also for his "global vision" of modern architecture in Australia, "integrated within and related with the world's overview." ${ }^{85}$ Only now, in 2017, Frampton admits that they "left out a big part of the world. (...) In the last revision (which at the time of writing this essay he is preparing for publication in 2017) I do not want to present a Eurocentric world: architecture in China, India, or Africa is also part of the planet." ${ }^{" 86}$ It will be interesting to investigate whether he offers a more complete account of Australia in this new edition of Modern Architecture: A Critical History.

Not only Frampton's Modern Architecture but every history considered in this study is informed by the Euro-American bias of their writers, which undoubtedly influences the absence and presence of Australian architecture. The case of Australia is also particular as a member of the Commonwealth

\footnotetext{
${ }^{85}$ Maluenda, "Latinoamérica en la historiografía moderna," 333. Author's translation into English.

${ }^{86}$ Anatxu Zabalbeascoa, "Kenneth Frampton: 'Los rascacielos no son arquitectura, solo dinero,"” El Pais Semanal (March 10, 2017), accessed March 14, 2017, http://elpaissemanal.elpais.com/confidencias/kenneth-frampton/?id_externo_rsoc=FB_CC.
} 
and, similarly to Canada, South Africa and New Zealand, its architecture has been considered to be mainly related to British architecture. The latter was also mis- or underrepresented in comparison with Central European architecture in the historiography of modern architecture deeply rooted in the German tradition of art history. In addition, the effects of postcolonial theory in architectural debate around 1999 resulted in what I would argue is a new field of historiography: the history of global architecture. ${ }^{87}$ Again, it will be interesting to investigate the absence and presence of Australian architecture in this field.

Meanwhile in Australia, the Society of Architectural Historians, Australia and New Zealand has held annual conferences since 1984 and has published Fabrications since 1989. Other journals have appeared such as Transition (published from 1979 to 2000) and Architectural Theory Review (1996). The research published through these forums could have been a perfect source for historians of modern architecture writing from 1980 onwards, but as noted by Philipp Goad and Julie Willis, the "triumvirate" of Australian architects writing history "continue to form the backbone of interpretation of architectural history in Australia," and the backbone of the account of Australia in architectural historiography. ${ }^{88}$ Goad and Willis argued that John Maxwell Freeland's Architecture in Australia-A History (1968), Donald Leslie Johnson's Australian Architecture 1901-51, Sources of Modernism (1980), and the numerous writings of Robin Boyd on the Australian environment have not yet been challenged. ${ }^{89}$

mong other scholars, Stanislaus Fung, Paul Walker, Julie Willis and Philip Goad start "from the very beginning, rejecting 'isms' and the attendant conceptual structures that would shape research,

\footnotetext{
${ }^{87}$ I draft the differences between these fields in the theoretical framework of my doctoral dissertation and I hope to trace the presence and absence of Australian architecture in the history of global architecture in a future research paper.

${ }^{88}$ Goad and Willis, “A Bigger Picture: Reframing Australian Architectural History," 19.

${ }^{89}$ John Maxwell Freeland, Architecture in Australia - a History (Melbourne/Canberra/Sydney: FW Cheshire, 1968).

Donald Leslie Johnson, Australian Architecture 1901-51, Sources of Modernism (Sydney, 1980).
} 
and suggest starting points for historical reflection." 90 Through careful and detail analysis of the foundations of historiographical categories, their research call their applicability into question, according to Andrew Leach, Antony Moulis and Nicole Sully. ${ }^{91}$ It is interesting to see how the recent histories and their frames of reference influenced this research environment and, reversely, its impact on the sources used in the most recent historiography.

Before moving on to the historians' sources, it is also necessary to point out that Australian modern architecture is portrayed often, since the last decades of the twentieth century, in relevant architectural journals such as Domus, Architectural Record, L'Architecture d'Aujourd'hui and The Architectural Review. For example, from 1990 Mauro Baracco wrote essays for Domus on Harry Seidler's extension of an office building in Sydney (12/1990) and on Nonda Katsalidis' house in St. Andrews Beach, Victoria (04/1996). In a recent architectural symposium on 'Italy/Australia: Postmodern in Translation', Silvia Micheli presented her research on a special issue on Australia in the architectural journal Domus (07/1985). Jahn Graham published journal articles on different buildings in Brisbane and Sydney in The Architectural Record. Another example is Philip Goad who wrote about Choong House in Eltham, Victoria in The Architectural Record (04/1988) and more generally about Australian architecture in L'Architecture d'Aujourd'hui (02/1993). The Architectural Review was other journal that featured Australian modern architecture, where Rory Spence wrote about 'regional identity' (12/1985) and Glenn Murcutt (05/1987) discussed 'the Griffin plan for Canberra and the Parliamentary Zone' (10/1988) and several architects and buildings. None of these publications were referenced by the historians discussed above.

\footnotetext{
${ }^{90}$ Andrew Leach, Antony Moulis and Nicole Sully, eds., Shifting Views: Selected Essays on the Architectural History of Australia and New Zealand (St Lucia, 2008), xi-xii.

${ }^{91}$ Leach, Moulis and Sully, Shifting Views, xii.
} 
In 1967, Giedion used as his source the writings of Utzon himself: two books published in 1962 and a paper that was published in Zodiac in 1965. Modern Movements (1973) has no bibliography and Jencks refers the reader to the notes for further literature. Sadly, there are no notes to accompany the different references that Jencks makes to the Opera House. As has been already mentioned, the tone of his argument suggests a critical response to Giedion's interpretation. The main sources for Frampton are Philip Drew's Leaves of Iron (1987), Haig Beck's and Jackie Cooper's Glenn Murcutt: A Singular Architectural Practice (2002), and Françoise Fromonot's Glenn Murcutt (2003). ${ }^{92}$ The only source that Cohen lists related to Australia is Fromonot's book on Glenn Murcutt. The fact that these historians have focussed mainly on the Sydney Opera House and the work of Murcutt explains the preference for monographic research on these themes.

The completeness of Curtis' account of modern architecture is built on more varied sources. In the case of the Opera House, he uses Giedion's and Drew's account of the third generation as a starting point and bases his interpretation also in Utzon's own writings. ${ }^{93}$ For a general treatment of arrival of modern architecture in Australia he proposes precisely Goad's and Willis' triumvirate.To understand the ideas behind houses in Sydney area and how they reflect a concern with place and identity, Curtis endorses Jennifer Taylor's An Australian Identity, Houses for Sydney 1953-1963 and a paper published in Transition by Winsome Callister. ${ }^{94}$ And, finally, he too recommends Fromonot's and Drew's work on Murcutt. For useful observations on the Sydney milieu of 1970s Curtis refers the reader to 'Australie,' a special issue of L'architecture d'aujourdhoui edited by Fromonot in 1993, and to Leon Paroissien's and Michael Griggs's Old Continent, New Building,

\footnotetext{
${ }^{92}$ Françoise Fromonot, Glenn Murcutt, oeuvres et projects (Paris, 1995). Philip Drew, Leaves of Iron, Pioneer of an Australian Architectural Form (Sydney, 1985).

${ }^{93}$ Jørn Utzon, “The Sydney Opera House,” Zodiac, no. 14 (1965), 49.

${ }^{94}$ Jennifer Taylor, An Australian Identity, Houses for Sydney 1953-1963 (Sydney, 1972). Winsome Callister, "Dealing with the 'Sydney School': Perspectives on Australian Architecture in the 1950s and 1960s," Transition (September 1987): 6-12.
} 
Contemporary Australian Architecture (1983). ${ }^{95}$ Sadly, there are no notes in reference to Burley Griffin's plan for Canberra or to Giurgola's plan for Parliament House. It can also be added that, despite the completeness of his sources, Curtis fails to acknowledge Jennifer Taylor's Australian Architecture Since 1960 (1986). ${ }^{96}$

The fact that Freeland's book "is still the only attempt at a national architectural history, and [that] its narrative remains persistent and pervasive, in spite of much research" published since 1968 seems to support the necessity to rewrite the history of Australian modern architecture. ${ }^{97}$ As it was pointed out in the 2014 annual conference of SAHANZ 'Translation,' the time is right to provide "a foundation upon which to build an alternate narrative in the history of Australian architecture," a more inclusive one, as demonstrated by the publication of Goad's and Willis' Encyclopedia of Australian Architecture (2012). ${ }^{98}$ This may be a first step towards a more complete inclusion of Australia in the future historiography of modern architecture, if somebody dare to make a new contribution to the field. Is there a more complete account of Australian modern architecture in the global histories of architecture? Most of the publications in this field are organised in different volumes for different regions, instead of presenting an intertwined narrative throughout the world and the different eras. It will be interesting to investigate this issue further in a future paper.

\section{Endnotes}

\footnotetext{
${ }^{95}$ Françoise Fromonot, ed., “Australie,” L'architecture d'aujourdhui, no. 285 (February 1993). Leon Paroissien and Michael Griggs, Old Continent, New Building, Contemporary Australian Architecture (Sydney: David Ell Press, 1983).

${ }^{96}$ Jennifer Taylor, Australian Architecture Since 1960 (Sydney: Law Book Co., 1986).

${ }^{97}$ David Beynon, Brandon Gardiner, Ursula de Jong, Mirjana Lozanovska and Flavia Marcello, "An Issues Paper: The Roots/Routes of Australian Architecture: Elements of an Alternative Architectural History," in Proceedings of the Society of Architectural Historians, Australia and New Zealand: 31, Translation, ed. Chistoph Schnoor (Auckland NZ: SAHANZ and Unitec ePress; and Gold Coast QL: SAHANZ, 2014), 642.

${ }^{98}$ Beynon et al., "An Issues Paper: The Roots/Routes of Australian Architecture: Elements of an Alternative Architectural History," 658.
} 


\section{University Library}

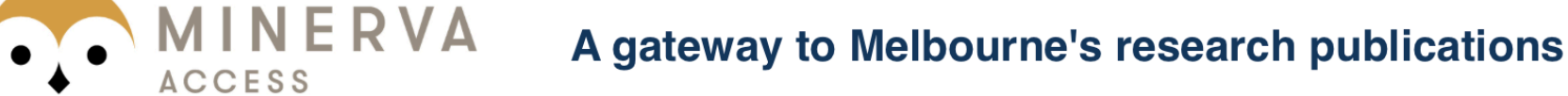

Minerva Access is the Institutional Repository of The University of Melbourne

Author/s:

de la Vega de León, M

Title:

A Tale of Inconsistency: The Absence and Presence of Australia in the Historiography of Modern Architecture

Date:

2018

Citation:

de la Vega de León, M. (2018). A Tale of Inconsistency: The Absence and Presence of Australia in the Historiography of Modern Architecture. Fabrications: the journal of the Society of Architectural Historians, Australia and New Zealand, 28 (1), pp.47-66. https:// doi.org/10.1080/10331867.2017.1394806.

Persistent Link:

http://hdl.handle.net/11343/290197 